Article

\title{
Periods of Extreme Shallow Depth Hinder but Do Not Stop Long-Term Improvements of Water Quality in Lake Apopka, Florida (USA)
}

\author{
Gaohua Ji ${ }^{1}$ (1) and Karl Havens ${ }^{2, *}$ \\ 1 National Demonstration Center for Experimental Fisheries Science Education, CREEFN of the Ministry \\ Agriculture and Shanghai Universities Key Laboratory of Marine Animal Taxonomy and Evolution, \\ Shanghai Ocean University, Shanghai 201306, China; ghji@shou.edu.cn \\ 2 Florida Sea Grant College Program, University of Florida Institute of Food and Agricultural Sciences, \\ Gainesville, FL 32611, USA \\ * Correspondence: khavens@ufl.edu; Tel.: +1-352-392-5870
}

Received: 17 December 2018; Accepted: 11 March 2019; Published: 15 March 2019

\begin{abstract}
We recently documented that during times of extreme shallow depth, there are severe effects on the water quality of one of the largest shallow lakes in the southeastern USA-Lake Apopka. During those times, total phosphorus (TP), total nitrogen (TN), chlorophyll- $a(\mathrm{Chl}-a)$ and toxic cyanobacteria blooms increase, and Secchi transparency (SD) declines. The lake recovers when water levels rise in subsequent years. In this paper, we determined whether extreme shallow depth events, particularly when they re-occur frequently, can stop the long-term recovery of a shallow eutrophic lake undergoing nutrient reduction programs. Apopka is an ideal location for this case study because the State of Florida has spent over 200 million USD in order to reduce the inputs of $\mathrm{P}$ to the lake, to build large filter marshes to treat the water, and to remove large quantities of benthivorous fish that contribute to internal P loading. We obtained data from 1985 to 2018, a period that had relatively stable water levels for nearly 15 years, and then three successive periods of extreme shallow depth, and we examined the long-term trends in TP, TN, Chl- $a$, and SD. There were significant decreasing trends in all of these water quality variables, and even though water quality deteriorated during periods of extreme shallow depth, and reduced the slope of the long-term trends, it did not stop the recovery. However, in the future, if climate change leads to more frequent shallow depth events, which in lakes such as Apopka, result in the concentration of water and nutrients, it is unclear whether the resilience we document here will continue, vs. the lake not responding to further nutrient input reductions.
\end{abstract}

Keywords: shallow lakes; depth; water quality; climate change; nutrients; lake management

\section{Introduction}

It is well-established that droughts, and associated periods of extreme shallow depth, can cause deteriorated water quality in eutrophic lakes, particularly when there is a substantive reduction in water volume. As examples, Bouvy et al. [1,2] observed elevated concentrations of total nitrogen $(\mathrm{TN})$, total phosphorus (TP), and chlorophyll-a (Chl-a), along with blooms of toxin-producing Cylindrospermopsis, in a Brazilian reservoir during a drought. Brasil et al. [3] confirmed that this was a widespread phenomenon in Brazil, occurring simultaneously in 40 shallow lakes. Ha et al. [4] reported an increase in nutrients and toxic Microcystis blooms in a Korean river during a severe drought, and Nõges et al. [5] found that the phytoplankton shifted from Lyngbya with no blooms to Anabaena and intense blooms in Lake Võrtsjärv, Estonia in a drought period that was linked to a particular phase of the North Atlantic Oscillation (NAO). The causes of observed drought effects 
were reviewed by Reichwald and Ghadouani [6], who identified a number of reasons why extreme shallow depth stimulates blooms of cyanobacteria, including warmer water, the concentration of nutrients in the reduced volume, stagnation, and greater nutrient transport from the lake sediments. We reached similar conclusions after studying the relationship between cyanobacteria blooms and water depth in seven central Florida lakes [7]. We recently found that in one of Florida's largest lakes, Lake Apopka, multi-year oscillations in depth were the major factor affecting TP, TN, Chl-a, and Secchi disk transparency (SD) in this lake over the period of time from 1999 to 2016 [8].

There is mounting evidence that with global warming, there will be more extreme droughts and concentrated rainfall in shorter and more intense events [9]. A question that has not been explored is whether recurring severe droughts and periods of extreme shallow depth can stop the response of lakes to programs aimed at improving water quality. In the case of Lake Apopka, approximately 200 million USD has been spent to reduce TP and phytoplankton Chl- $a$, increase SD transparency, and re-establish submerged vascular plants [10-12], which were lost from the lake in the late 1950's due to high nutrient concentrations and/or effects of a hurricane [13]. Lake rehabilitation programs have included: purchasing a large area of former agricultural land north of the lake to reduce $\mathrm{P}$ loads, restoring it to wetland habitat [14], constructing a large wetland treatment system to filter algal cells from the lake water [15], and removing large quantities of benthivorous fish from the lake by commercial gill netting after documenting that their activities contribute to the high internal $\mathrm{P}$ loading [11,16,17]. Our study from 1999 to 2016 indicated that there were no significant downward trends in TP, TN, Chl- $a$ and no significant increase in SD [8] despite the ongoing lake restoration actions. However, the intent of that study was only to document the effects of three successive shallow depth events on water quality in a case study, and not to evaluate the efficacy of the Lake Apopka restoration program. As such, we did not explore the entire period of water quality records.

Here, we evaluate the full water quality dataset from Lake Apopka, from 1985 to 2018. This includes a prolonged period when depth was relatively stable, from 1985 to 1998, and during the aforementioned events of extreme shallow depth. Because water quality data were collected at least monthly during the 33-year period, we could evaluate the degree to which three back-to-back shallow depth events stopped the progress of lake restoration. This brings the influence of water depth into the realm of eutrophication management, and as such, it has implications on how climate change may influence outcomes of restoration programs in other shallow lakes if it changes the frequency or intensity of droughts and other factors that influence depth.

\section{Materials and Methods}

\subsection{Description of the Lake}

Lake Apopka $\left(125 \mathrm{~km}^{2}\right.$, mean depth $1.65 \mathrm{~m}$, maximum depth $\left.5 \mathrm{~m}\right)$ is located in central Florida at $28^{\circ} 37^{\prime} \mathrm{N}$ latitude, $81^{\circ} 38^{\prime} \mathrm{W}$ longitude (Figure 1 ). The volume of the lake varied from a low of $62 \times 10^{6} \mathrm{~m}^{3}$ to a high of $247 \times 10^{6} \mathrm{~m}^{3}$, with a median of $182 \times 10^{6} \mathrm{~m}^{3}$ during the study period. The $485 \mathrm{~km}^{2}$ watershed has mixed land uses, including agriculture, urban, residential, and wetlands. Water enters the lake by rainfall directly on the surface, by a spring at the southern end, by pumping from the surrounding land during heavy rainfall events, and by infiltration of groundwater into the lake. Water exits the lake by evaporation and through a single man-made canal, which was constructed in the late 19th century. The canal connects Lake Apopka to a group of downstream lakes called the Harris Chain [7]. Typically, the water residence time of the lake is 2-6 years, but under extreme conditions can be as low as 1.6 or as high as 30 years [16]. 


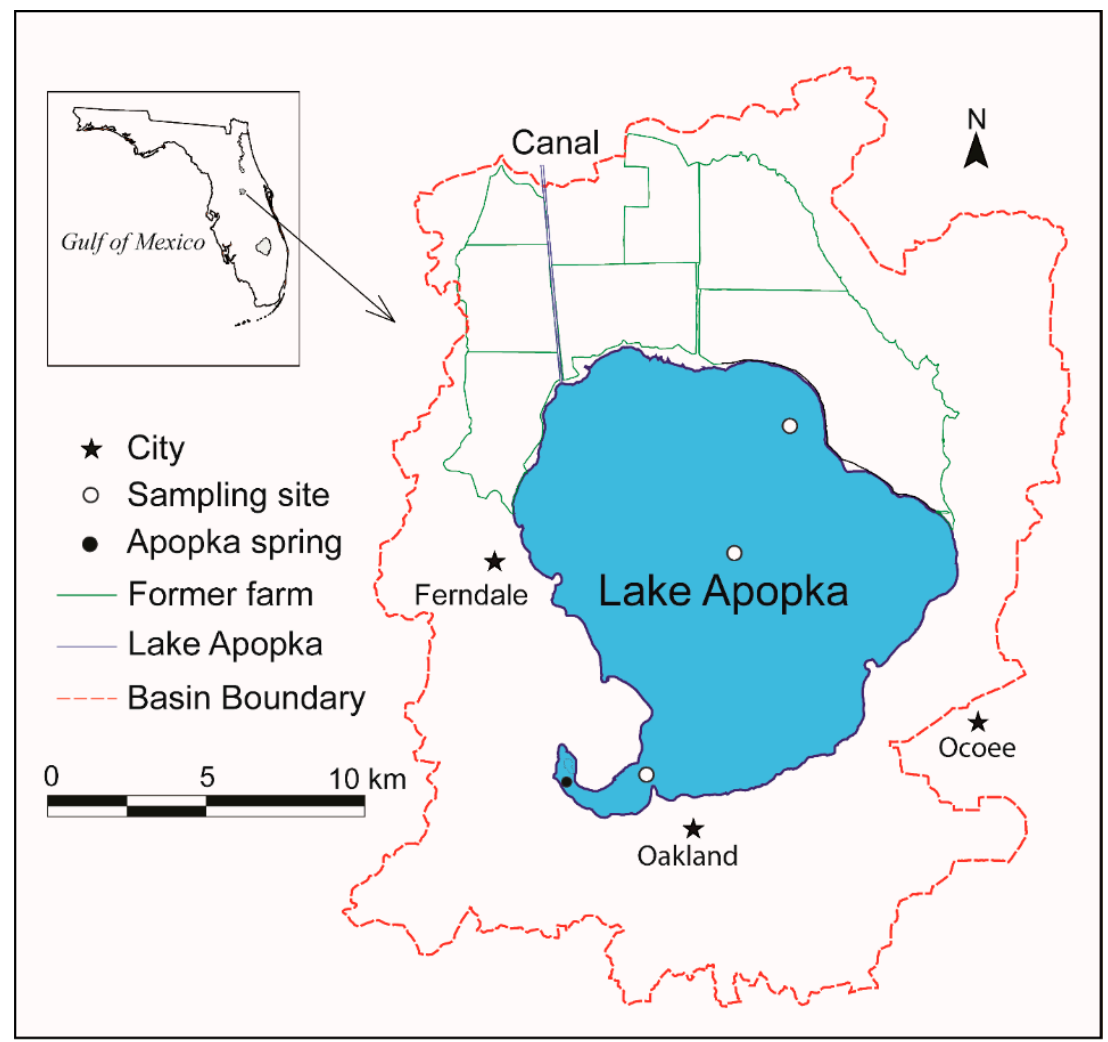

Figure 1. Lake Apopka in Florida, USA, indicating the three pelagic sampling sites, the boundary of the drainage basin, and the former farms that are wetlands now.

Lake Apopka is hypereutrophic, lacks any substantial coverage of submerged aquatic vegetation, and is dominated by cyanobacteria [16]. More than $90 \%$ of the lake bottom is covered with unconsolidated organic muck with high concentrations of $P$ and $N$ [14]. The sediment is mostly fluid organics ( $98 \%$ water), and it is easily disturbed by wind and by bioturbation from benthivorous fish [18]. Since the 1960s, there has been a 6-fold reduction in the external P load to the lake, as well as possible reductions of internal $\mathrm{P}$ sources, from the aforementioned projects to filter water and remove fish [13].

\subsection{Sampling}

We used the monthly water quality data that are collected by the St. Johns River Water Management District as part of a long-term lake monitoring program. The period of record is from August 1985, when sampling began, to August 2018, the most recently available data. A subset of this same dataset was used by Havens and Ji [8] in the previous assessment of the effects of rainfall and water depth on this lake. Sampling in each month was done in north, south, and central sites (Figure 1). Water quality data were averaged by date across the three sites. Water temperature was measured at 0.5 $m$ depth with a YSI or Hydrolab sonde, and SD transparency was measured with a 20-cm Secchi disk. Water samples were collected and preserved following US Environmental Protection Agency (USEPA) methods [19] for TP, TN, and Chl- $a$. Laboratory measurements also followed USEPA standards [19] for TN, TP, and corrected Chl- $a$. The surface elevation of the lake, in meters relative to mean sea level, was determined from a stage gauge. Surface elevations were converted to mean depth as lake volume/lake area, with volume based on a polynomial equation that was developed from a 2007-2008 survey (St Johns River Water Management District, unpublished data) of the lake's bathymetry and the topography of near-shore periodically-flooded land. Likewise, surface areas were based on the same survey, with values related to the surface elevation at $0.3 \mathrm{~m}$ increments. The location for measuring 
surface elevation changed in 2013; however, simultaneous measurements at new and old locations were done for more than a year, and the average difference was just $0.0012 \mathrm{~m}$.

\subsection{Statistical Analyses}

Data were analyzed in Systat 13 and $\mathrm{R}$ with nonparametric methods. We examined historical trends using two methods. First, a Mann-Kendall trend test was used to determine whether there were statistically significant trends in TP, TN, Chl- $a$, and SD for the 1985 to 2018 period. Where significant trends were detected, we compared the starting and ending values that were calculated by regression formula to approximate the percent change. We also compared the slopes of two models that included and excluded data from the three low-water periods using a dummy variables method [20]. We then looked at data only from the high-water periods (depth $\geq 1.5 \mathrm{~m}$ ), that is, from 1985 to 1998, 2003 to 2006, 2009 to 2011, and 2015 to 2018. This was done in order to compare water quality without the confounding influence of extreme shallow periods. For each period box, the whisker plots were constructed for TP, TN, Chl- $a$, and SD and a non-parametric analysis was done to compare the differences among the four-time blocks. A Kruskal-Wallis test was made to compare the four groups of data, and the result showed that all the parameters were significantly different among groups $(p<0.01)$. Then, we performed Mann-Whitney tests to find significant differences between each pairwise groups $(p<0.01)$. Outliers accounted for less than $5 \%$ of the data and were not excluded from any of the statistical analyses.

\section{Results}

From 1985 to 1998 (Period 1), the mean depth of the lake was seasonally variable but stayed within the range of 1.40 to $1.96 \mathrm{~m}$, and it was greater than $1.50 \mathrm{~m}$ in most cases (Figure 2). Then, in the period between 2000 and 2015, there were three events where the lake depth dropped to $0.61,0.86$, and $0.95 \mathrm{~m}$. The lake depth was highly correlated with the cumulative amount of rainfall during the previous 25 months $(r=0.77, p<0.001)$. After 2000, there were three periods when the depth was greater than or equal to $1.50 \mathrm{~m}$, that is, March 2003 to April 2006 (Period 2), July 2009 to May 2011 (Period 3), and August 2015 to July 2018 (Period 4).

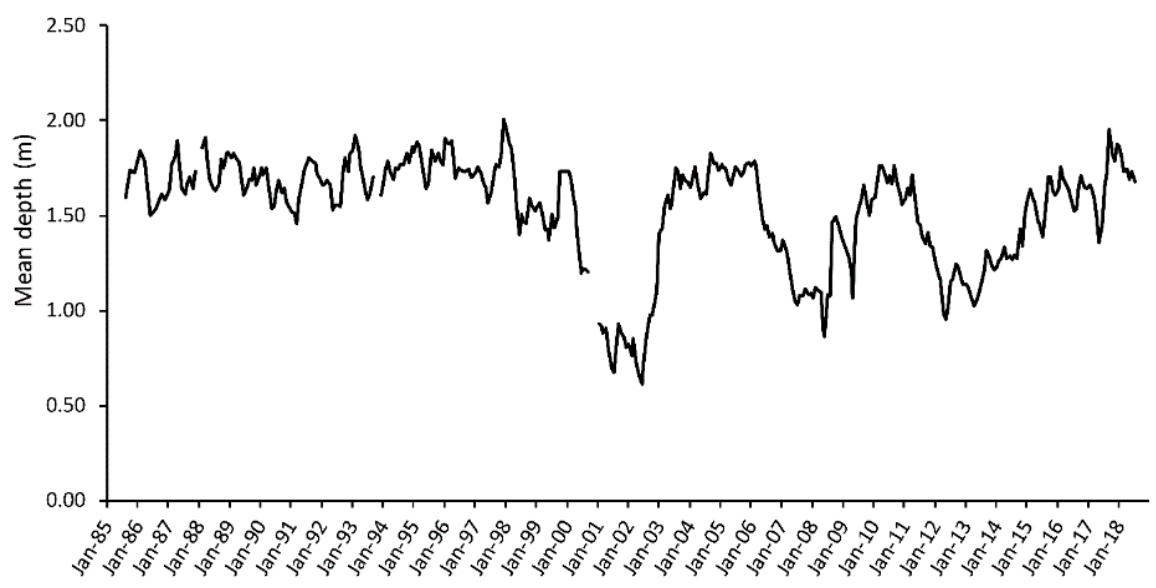

Figure 2. The history of variation in mean lake depth during the period when water quality data have been collected from 1985 to 2018.

Overall, water quality improved during the 32 years of record (Figure 3). The results of Mann-Kendall trend tests for raw monthly data from 1985 to 2018 indicated significant decreasing trends in TP, TN, and Chl- $a$, as well as an increasing trend in SD $(p<0.001)$. Based on a linear model, TP dropped from 233 to $83 \mu \mathrm{g} \mathrm{L}^{-1}(64 \%)$ in the study period. There was also a $21 \%$ reduction of TN (from 5.1 to $4 \mathrm{mg} \mathrm{L}^{-1}$ ) and a $34 \%$ reduction of Chl- $a$ (from 86 to $57 \mu \mathrm{g} \mathrm{L}^{-1}$ ). SD was increased, from 23 to $30 \mathrm{~cm}(31 \%)$. 

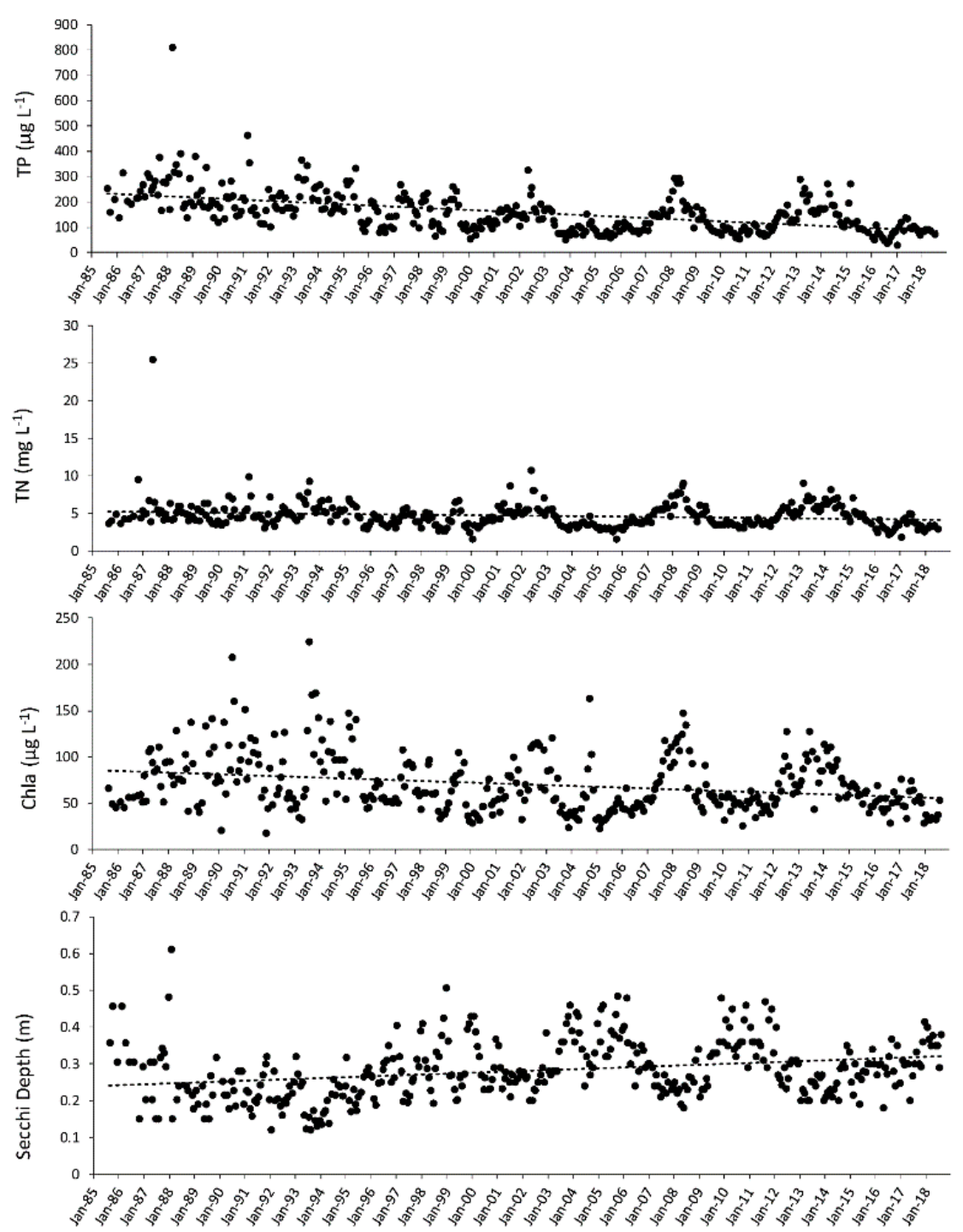

Figure 3. The long-term trends in water quality. All the trends are significant $(p<0.001)$. TP: total phosphorus, TN: total nitrogen, chl-a: chlorophyll-a.

As documented in an earlier study, water quality was highly influenced by lake depth. In particular, TP, TN, and Chl- $a$ all increased during the three extreme shallow periods, that is, 2000 to 2002,2007 to 2008,2012 to 2014 , and SD declined. To quantify the degree to which those extreme events affected the long-term trends, we excluded data from those time periods, when depth was $<1.5 \mathrm{~m}$, and performed the trend test again. The downward regression slopes were greater (Figure 4), and the improvements in water quality were enhanced. TP, TN, and Chl- $a$ declined by $81 \%, 42 \%$, and $53 \%$, respectively, and SD increased by $60 \%$. 

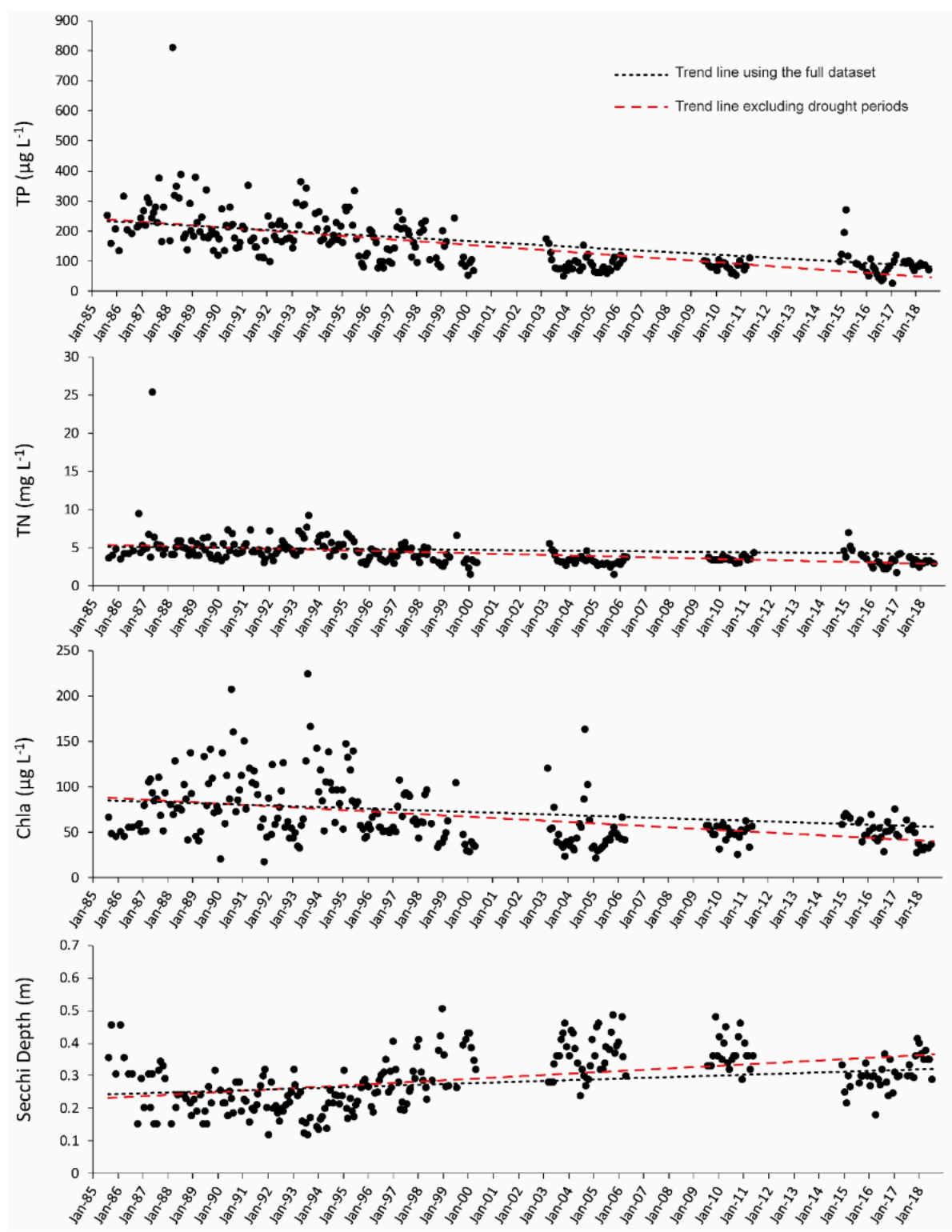

Figure 4. The long-term trends in water quality excluding those data during droughts. All the trends are significant $(p<0.001)$. TP: total phosphorus, TN: total nitrogen, chl-a: chlorophyll-a.

Large-scale improvements in water quality happened between 1985 and 2018 when looking only at data with comparable water depths (Figure 5). The mean TP was $207 \mu \mathrm{g} \mathrm{L}^{-1}$ during the first period but fell to $91 \mu \mathrm{g} \mathrm{L}^{-1}$ in the second period $(p<0.001)$ and this change persisted in the third and fourth time periods. The same patterns were found for TN, Chl-a, and SD, except that SD declined somewhat in the most recent period of record. 

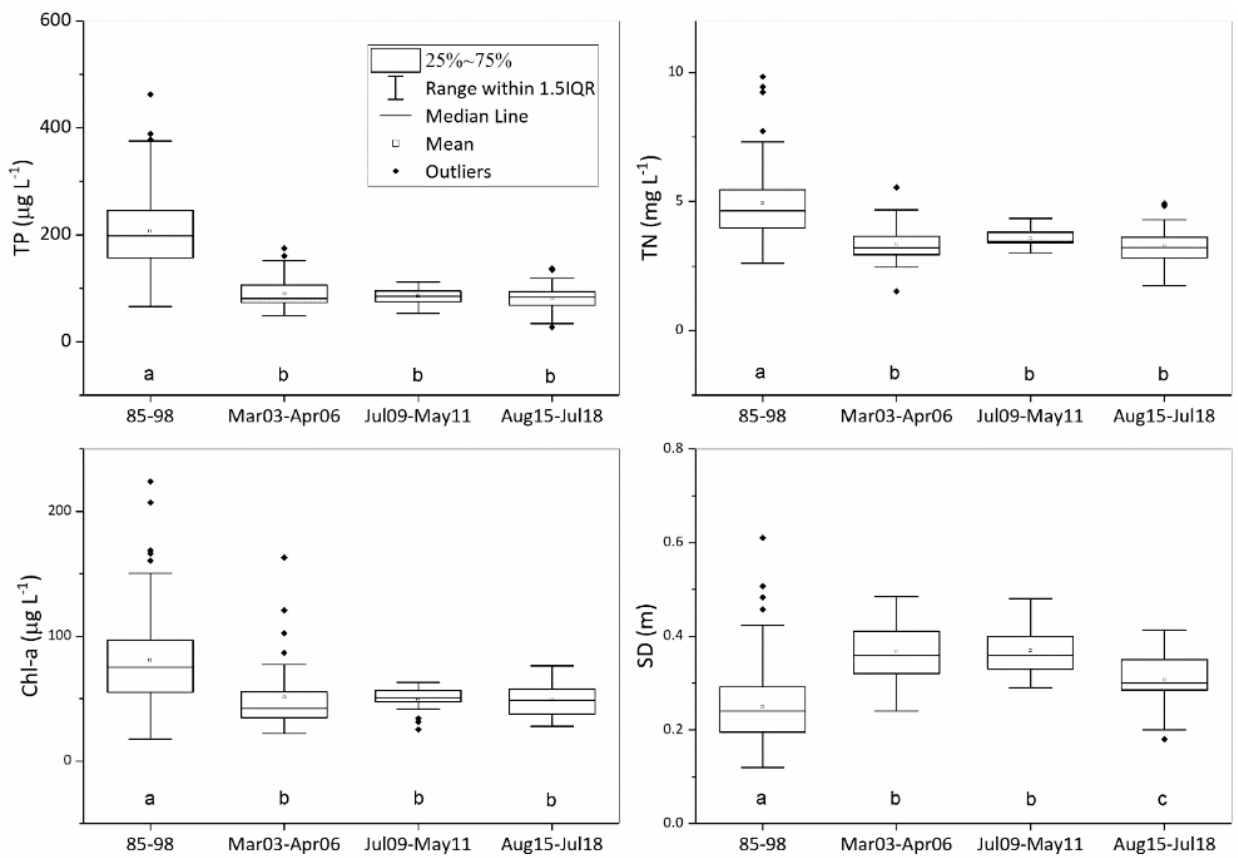

Figure 5. Comparison of water quality in the four wet periods by whisker plots. If one of the letters in one group is the same as the one from the other group, there is no significant difference between these groups. TP: total phosphorus, TN: total nitrogen, chl-a: chlorophyll-a, SD: Secchi transparency.

\section{Discussion}

The observed declines in TP, TN, Chl- $a$ and an increase in SD documented here between 1985 and 2018 might be a result of the restoration projects conducted by the state around and in the lake, including a large-scale purchase of farmland north of the lake and conversion to wetland conservation land [16] and harvesting of omnivorous fish to reduce internal P cycling from the sediments to water column [15-17].

The three periods of extreme shallow depth that happened after 2000 had a major influence on all of the water quality attributes. As reported before [16], the concentration of TP jumped to a high of $300 \mu \mathrm{g} \mathrm{L}^{-1}$ when the lake reached its lowest depth in May 2002, and the lake volume during that severe drought was only $25 \%$ of its long-term mean volume. Chl- $a$ concentrations increased, and SD declined. As we discussed previously [8], it is likely that during shallow depth periods, the reduced lake volume concentrated nutrients, enhanced the relative effects nutrient mobilization by benthivorous fish, and resulted in a loss of cladoceran zooplankton due to intensified fish predation. Periods of extreme shallow depth also coincided with stagnation (little or no water movement into or out of the lake), and this further supports the development of cyanobacteria blooms that happened to coincide with the elevated TP and TN in the water column [7].

In regard to lake responses to the restoration programs, the three droughts temporarily masked the beneficial effects, yet as severe as those events were, in the long-term, they only influenced the recovery trend by 22 percent. Further, the drought-induced changes in water quality quickly reversed when depth increased, even after a third successive shallow depth event.

Water quality in other shallow eutrophic lakes has deteriorated during droughts for the reasons noted above, including: (1) residence time is prolonged [21] and, in some lakes, the lake stratification is more stable [22], (2) shallower depth makes sediments and meroplankton more susceptible to mixing into the overlying water during high wind events [23]; (3) the concentrated fish continue their searching of food in sediments [17], pumping nutrients into a lake of reduced volume [7], and (4) water temperature becomes warmer and this favors bloom-forming cyanobacteria [24] that can migrate from the sediments to the water column, carrying nutrients [6]. The last condition, warming, was not observed in this study. 
Droughts are expected to become more frequent and/or prolonged in certain regions of the world with climate change [9] and have been found to influence water quality all over the world. In the Ingazeira Reservoir of Brazil, the water became hypertrophic with the bloom of filamentous cyanobacteria from 1997 to 1998, coincident with a severe drought linked to an El Niño [1]. Brasil et al. [3] found that drought impacted the hydrological, chemical, and physical characteristics of man-made lakes and aggravated the symptoms of eutrophication in tropical semiarid regions, favoring cyanobacteria blooms. In Lake Võrtsjärv, Estonia, the water became shallower, and TP and Chl- $a$ increased when the North Atlantic Oscillation (NAO) caused drought conditions [5]. In Lakes Alexandrina and Albert in Australia, TP, TN, and Chl- $a$ significantly increased during the drought caused by low rainfall [25]. In Apopka, we have shown previously [7] that reduced residence time during periods of extreme shallow depth contributed to cyanobacteria blooms. We lack the information to investigate whether or not stratification regime and potential mixing also change and affect water quality.

Many lakes in the world are undergoing costly restoration processes, such as Lakes Taihu and Dianchi in China [26,27] and Lake Apopka in Florida [16], in order to improve water quality [28]. It is critical to know whether or not severe droughts can prevent recovery of better water quality for a long period of time, or have just short-lasting effects. In this study, the first to address this issue, we identified that the effects of severe droughts and large reductions in water volume did interrupt recovery, but very quickly the lake regained the benefits from nutrient reduction programs. We are not aware of any other studies documenting such rapid recovery of water quality after droughts ended, which indicates a high degree of resilience. Additional research is needed to fully understand how periods of extreme shallow depth that often are associated with droughts might influence lake restoration programs, because Lake Apopka might not reflect what will occur in different kinds of lakes, for example, those that can support rooted vascular plants during times of shallow depth. Further, it needs to be determined whether shallow lakes in general, including those with and without submerged plants, will at some point lose the resilience observed here if droughts occur at a higher frequency with future climate change.

Author Contributions: G.J. conducted the data analysis and wrote the final draft. K.H. analyzed the data and developed the first draft of the manuscript.

Acknowledgments: The authors are grateful to the St. Johns River Water Management District for providing water quality data and to three anonymous reviewers for providing constructive comments. The research was not supported by any external funding.

Conflicts of Interest: The authors declare no conflict of interest.

\section{References}

1. Bouvy, M.; Molica, R.; Oliveira, S.D.; Marinho, M.; Beker, B. Dynamics of a toxic cyanobacterial bloom (Cylindrospermopsis raciborskii) in a shallow reservoir in the semi-arid region of northeast Brazil. Aquat. Microb. Ecol. 1999, 20, 285-297. [CrossRef]

2. Bouvy, M.; Falcão, D.; Marinho, M.; Pagano, M.; Moura, A. Occurrence of Cylindrospermopsis (Cyanobacteria) in 39 Brazilian tropical reservoirs during the 1998 drought. Aquat. Microb. Ecol. 2000, 23, 13-27. [CrossRef]

3. Brasil, J.; Attayde, J.L.; Vasconcelos, F.R.; Dantas, D.D.F.; Huszar, V.L.M. Drought-induced water-level reduction favors cyanobacteria blooms in tropical shallow lakes. Hydrobiologia 2016, 770, 145-164. [CrossRef]

4. Ha, K.; Cho, E.-A.; Kim, H.-W.; Joo, G.-J. Microcystis bloom formation in the lower Nakdong River, South Korea: Importance of hydrodynamics and nutrient loading. Mar. Freshw. Res. 1999, 50, 89-94. [CrossRef]

5. Nõges, T.; Nõges, P.; Laugaste, R. Water level as the mediator between climate change and phytoplankton composition in a large shallow temperate lake. Hydrobiologia 2003, 506, 257-263. [CrossRef]

6. Reichwaldt, E.S.; Ghadouani, A. Effects of rainfall patterns on toxic cyanobacterial blooms in a changing climate: Between simplistic scenarios and complex dynamics. Water Res. 2012, 46, 1372-1393. [CrossRef] [PubMed]

7. Havens, K.E.; Ji, G.; Beaver, J.R.; Fulton, R.S.; Teacher, C.E. Dynamics of cyanobacteria blooms are linked to the hydrology of shallow Florida lakes and provide insight into possible impacts of climate change. Hydrobiologia 2017. [CrossRef] 
8. Havens, K.E.; Ji, G. Multiyear oscillations in depth affect water quality in Lake Apopka. Inland Waters 2018, 8, 1-9. [CrossRef]

9. The Core Writing Team; Pachauri, R.K.; Meyer, L. 2014: Climate Change 2014: Synthesis Report; IPCC: Geneva, Switzerland, 2014; Volume 151.

10. Conrow, R.; Lowe, E.F.; Coveney, M.F.; Rauschenberger, R.H.; Masson, G. Restoration of Lake Apopka's North Shore Marsh: High Hopes, Tough Times, and Persistent Progress. In Wildlife Ecotoxicology: Forensic Approaches; Elliott, J.E., Bishop, C.A., Morrissey, C.A., Eds.; Springer: New York, NY, USA, 2011; pp. 189-211. [CrossRef]

11. Hoge, V.R.; Conrow, R.; Stites, D.L.; Coveney, M.F.; Marzolf, E.R.; Lowe, E.F.; Battoe, L.E. SWIM (Surface Water Improvement and Management) Plan for Lake Apopka, Florida; St Johns River Water Management District: Palatka, FL, USA, 2003.

12. Sutton, F. Cost of Bringing Lake Apopka Back to Life. Available online: https://www.wftv.com/news/9investigates /9-investigates-cost-of-bringing-lake-apopka-back-to-life/495058639 (accessed on 17 February 2017).

13. Coveney, M.F. Water Quality Changes in Lake Apopka, Florida, and the St. Johns River Water Management District's Restoration Program; St. Johns River Water Management District: Palatka, FL, USA, 2016.

14. Bachmann, R.; Hoyer, M.; Canfield, D., Jr. The restoration of Lake Apopka in relation to alternative stable states. Hydrobiologia 1999, 394, 219-232. [CrossRef]

15. Coveney, M.F.; Stites, D.L.; Lowe, E.F.; Battoe, L.E.; Conrow, R. Nutrient removal from eutrophic lake water by wetland filtration. Ecol. Eng. 2002, 19, 141-159. [CrossRef]

16. Coveney, M.F.; Lowe, E.F.; Battoe, L.E.; Marzolf, E.R.; Conrow, R. Response of a eutrophic, shallow subtropical lake to reduced nutrient loading. Freshw. Biol. 2005, 50, 1718-1730. [CrossRef]

17. Schaus, M.H.; Godwin, W.; Battoe, L.; Coveney, M.; Lowe, E.; Roth, R.; Hawkins, C.; Vindigni, M.; Weinberg, C.; Zimmerman, A. Impact of the removal of gizzard shad (Dorosoma cepedianum) on nutrient cycles in Lake Apopka, Florida. Freshw. Biol. 2010, 55, 2401-2413. [CrossRef]

18. Schelske, C.L. Comment on the origin of the "fluid mud layer" in Lake Apopka, Florida. Limnol. Oceanogr. 2006, 51, 2472-2480. [CrossRef]

19. Kopp, J.F.; McKee, G.D. Methods for Chemical Analysis of Water and Wastewater; United States Environmental Protection Agency: Washington, DC, USA, 1983.

20. Andrade, J.M.; Estévez-Pérez, M.G. Statistical comparison of the slopes of two regression lines: A tutorial. Anal. Chim. Acta 2014, 838, 1-12. [CrossRef] [PubMed]

21. Davis, H.; Goerner, S.; Powers, R.; Grow, S.; Johnson, R.; Nicholson, D.; Schlein, E.; Truenow, K.; Woosley, L. Harris Chain of Lakes Restoration Council Report to the Florida Legislature; Harris Chain of Lakes Restoration Council: Fruitland Park, FL, USA, 2013.

22. Havens, K.E.; Phlips, E.J.; Cichra, M.F.; Li, B.L. Light availability as a possible regulator of cyanobacteria species composition in a shallow subtropical lake. Freshw. Biol. 1998, 39, 547-556. [CrossRef]

23. Carrick, H.J.; Aldridge, F.J.; Schelske, C.L. Wind Influences phytoplankton biomass and composition in a shallow, productive lake. Limnol. Oceanogr. 1993, 38, 1179-1192. [CrossRef]

24. Paerl, H.W.; Huisman, J. Blooms Like It Hot. Science 2008, 320, 57-58. [CrossRef] [PubMed]

25. Li, S.Y.; Bush, R.T.; Mao, R.; Xiong, L.H.; Ye, C. Extreme drought causes distinct water acidification and eutrophication in the Lower Lakes (Lakes Alexandrina and Albert), Australia. J. Hydrol. 2017, 544, 133-146. [CrossRef]

26. Wang, Y.C.; Wang, W.B.; Wang, Z.; Li, G.B.; Liu, Y.D. Regime shift in Lake Dianchi (China) during the last 50 years. J. Oceanol. Limnol. 2018, 36, 1075-1090. [CrossRef]

27. Gao, H.L.; Qian, X.; Wu, H.F.; Li, H.M.; Pan, H.; Han, C.M. Combined effects of submerged macrophytes and aquatic animals on the restoration of a eutrophic water body-A case study of Gonghu Bay, Lake Taihu. Ecol. Eng. 2017, 102, 15-23. [CrossRef]

28. Zhou, Y.Q.; Ma, J.R.; Zhang, Y.L.; Qin, B.Q.; Jeppesen, E.; Shi, K.; Brookes, J.D.; Spencer, R.G.M.; Zhu, G.W.; Gao, G. Improving water quality in China: Environmental investment pays dividends. Water Res. 2017, 118, 152-159. [CrossRef] [PubMed]

(C) 2019 by the authors. Licensee MDPI, Basel, Switzerland. This article is an open access article distributed under the terms and conditions of the Creative Commons Attribution (CC BY) license (http:/ / creativecommons.org/licenses/by/4.0/). 